\title{
Restructuring of coal mining in Romania between the climate crisis and the energy transition
}

\author{
Cristian Tomescu ${ }^{1 *}$, Doru Cioclea ${ }^{1}$, Cornel Boanta ${ }^{1}$, and Marius Morar ${ }^{1}$ \\ ${ }^{1}$ National Institute for Research and Development in Mine Safety and Protection to Explosion \\ INSEMEX, 32-34 G-ral Vasile Milea Street, Postcode: 332047, Petrosani, Hunedoara County, \\ Romania
}

\begin{abstract}
The Romanian energy market is dependent on about a third of total production on the use of fossil fuels, hard coal and lignite and natural gas, especially in the winter months or dry summers, coal still being of strategic importance in producing electricity and ensuring energetic security. However, the sharp changes in climate in recent years have led to the conclusion of environmental agreements, with objectives aimed at long-term strategies to reduce greenhouse gas emissions and which clearly require a reduction in the capacity to produce one kilowatt of thermal energy and identify solutions for transition to clean energy. Where will the Hunedoara Energy Complex and the Oltenia Energy Complex be located in this context? This paper aims to analyze the process of restructuring coal mining, the competitiveness of coal in the electricity mix and possibly the future prospects of restructured mining areas.
\end{abstract}

\section{Introduction}

The climate crisis describes global warming, climate change, and their consequences, in a new concept promoted by the scientific community concerned about this phenomenon, which creates a state of emergency with a strong emotional impact and conveying a sense of awareness and responsibility in adopting measures to conserve the biosphere, reduce fossil fuel consumption and greenhouse gas emissions.

Amid growing concern regarding climate changes, the fossil fuel industry and especially extraction, processing and use of coal is considered, by environmental organizations, as the main culprit for the climate crisis, although in the context of Romania's energy strategy, coal is the primary energy resource in the energy mix, being a strategic fuel in support of national and regional energy security [1].

Constrained by imposition of the EU conditions for restructuring of mining and energy sectors, Romania is obliged to phase out the productive capacities of the two energy complexes on coal and lignite, in a period of 10 years, through a national plan on energy and climate to reduce greenhouse gas emissions by $50-55 \%$ compared to 1990 emissions, in line

${ }^{*}$ Corresponding author: cristian.tomescu@,insemex.ro 
with the European Green Pact. Romania is committed through the Integrated National Plan in the field of Energy and Climate Change 2021-2030 to reduce GHG emissions by $43.9 \%$, by 2030 , compared to values recorded in 2005 and to increase the global share of energy from renewable sources in gross final energy consumption with $30.7 \%$.

The energy transition refers to the transition from fossil and nuclear fuel to renewable energy sources, in order to create a new, efficient energy system with almost zero $\mathrm{CO}_{2}$ emissions. In another concept, it represents a fundamental transformation of our societies and affects everyone's daily life. It is not just about climate change, reducing greenhouse gas emissions and use of new technologies, the energy transition is also an opportunity for structural change, with active participation of citizens. What socio-economic impact will this transition have in the counties producing electricity and heat?

Analysis of the current situation of the Romanian coal mining will provide a real image of the extractive industry's decline in the last decades and, implicitly, of the decrease of coalbased electricity production.

\section{Regression of the coal sector and energy reserves}

In Romania today, coal is used up to a third of electricity production, although the installed and available power in the National Energy System (SEN) of coal-based units is 4,700 MW, of which below 2,000 MW are used for average consumption.

Underground coal production is carried out by the Mining Division of the Hunedoara Energy Complex (CEH), through four mining units (M.U. Lonea, M.U. Livezeni, M.U. Vulcan, M.U. Lupeni) with a staff of 2000 employees. In July of this year, 777 workers were laid off under the conditions of Government Ordinance no. 60/24.06.2021.

During two decades, 11 mining objectives were closed in the Jiu Valley (fig. 1), of which 2 at the end of 2018 ceased their extraction activity (Paroseni and Uricani mines), and by 2022, the Lonea and Lupeni mine are scheduled for cessation of exploitation.

Production capacities at the 4 mining units are ensured by 4 undermined bench workings and a mechanized working. Coal supply at the level of current Romanian producers is lower than the demand. Annual coal production has steadily fallen from 12 million tonnes in 1989 to 0.43 million tonnes in 2020 .

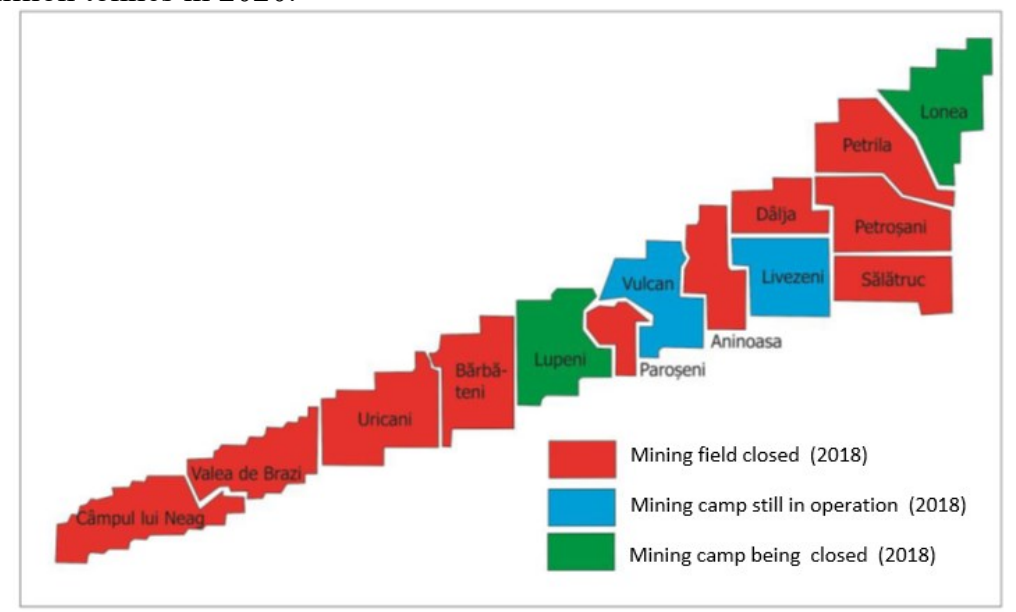

Source: Anastasiu et al., 2019 [2].

Fig. 1. Petrosani Basin: open, closed or under closure mining fields

The Romanian lignite producer, in proportion of $95 \%$, is the Oltenia Energy Complex, structured in 5 Carboniferous Basins (Rovinari, Motru, Jilt Husnicioara and Berbesti) within 
which there are 12 opencast mining units (quarries), with an annual production of 13,2 million tons (achieved in 2020), with a workforce of 12,250 employees, of which 662 were made available in accordance with the same ordinance 60/2021, mentioned above. Lignite extraction process in opencast units is performed in continuous flow, with SRs 1300 , SRs1400, SRs2000 bucket-wheel excavators, on working steps with heights of 25-30 m and excavation capacities between 2,800 and $4,500 \mathrm{~m}^{3} / \mathrm{h}$ (fig.2). Restructuring of lignite production required the closure and greening of 52 production units (mines and quarries).

Jiu Valley's coal production is used for production of electricity and heat in two thermal power plants, Paroseni and Mintia, located in Hunedoara County and provides $2 \%$ of the country's energy production. The known hard coal resources in Romania are 232 million tons ( 85 million tep), of which 83 million tons ( 30 million tep) can be exploited in concessional perimeters. At an average consumption of 0.3 million tep/year, coal resources are insured for 104 years, but exploitation of this primary energy resource is conditioned by economic feasibility of exploitations [3].

The Oltenia Energy Complex provides $30 \%$ of the energy production, within the four thermal energy units located in Gorj and Dolj counties. Lignite resources in Romania are estimated at 690 million tons (124 million tep), of which 290 million tons (52 million tep) can be exploited in concessional perimeters. At an average consumption of resources of 4.5 million tep/year, lignite resources are insured for 30 years, provided that the consumption will remain constant and no other lignite deposits will be exploited [4].

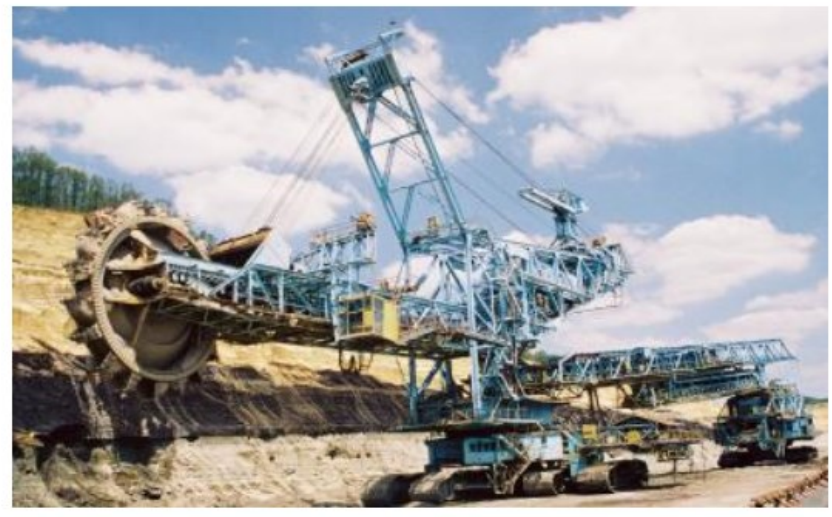

Fig. 2. Opencast lignite exploitation

In 2021, Romania's net coal production came, in the 5 months, to 1287.0 thousand tons of oil equivalent, being 263 thousand tep higher than the same period of the previous year according to data centralized by the National Institute of Statistic (INS) [5].

In the last five years (period 2016-2020) production of coal and lignite (the figures refer to planned production, except for 2017) has been in decline as indicated by data in table 1 .

Table. 1. Net production achieved 2016-2020 (tons).

\begin{tabular}{|l|c|c|c|c|c|}
\hline \multicolumn{1}{|c|}{ Coal producers } & $\mathbf{2 0 1 6}$ & $\mathbf{2 0 1 7}$ & $\mathbf{2 0 1 8}$ & $\mathbf{2 0 1 9}$ & $\mathbf{2 0 2 0}$ \\
\hline C E Hunedoara (pit coal) & 754,269 & 588,427 & 538,092 & 410,763 & 428,368 \\
\hline C E Oltenia (lignite) & $19,659,553$ & $22,654,718$ & $21,207,000$ & $19,785,185$ & $13,182,396$ \\
\hline
\end{tabular}


Although exploitable resources allow the continued activity of extractive industry, there are other factors that require restriction of exploitation and reconsideration of the energy strategy at national level:

- constraints imposed by environmental legislation, reduction of polluting gases' emissions (sulphur dioxide and nitrogen oxides) and greenhouse gases (methane and carbon dioxide), to achieve the EU objectives on climate change presented in the Draft Integrated National Plan in the field Energy and Climate Change (PNIESC) for the period 2021-2030;

- human resources are aging; most workers are over 40 years old in coal mining and over 50 years in lignite mining;

- exploitation technologies are physically and morally worn out;

- investments in new exploitation technologies are reduced, as no state aid is granted, except for the closure and greening of mining perimeters;

- dependence of coal production on the operation of a small number of energy production capacities;

- targeting other primary energy resources.

\section{Coal competitiveness - analysis and interpretation}

Current Romanian thermal energy infrastructure has been built over many decades, to support the use of conventional energy sources and especially coal. At present, our country ranks first in Southeast Europe with a total productive capacity of 20,000 MW of electricity, but more than a third of the productive capacity exceeds 48 years of operation and only $15 \%$ of the capacity has been put in operation in the last decade [6].

Paroseni Thermal Power Plant with an installed capacity of $150 \mathrm{MW}$, in an energy group, was designed to operate as a restarting capacity of the National Energy System, refurbished through an integrated project for the Jiu Valley, externally funded by a renowned Japanese consortium in the purpose of capitalizing on coal in new cogeneration plants and increased efficiency. However, the electricity produced here cannot compete with other cheaper energy sources in the energy market, because it produces energy at an uncompetitive price.

Mintia thermal power plant with an installed capacity of $1,285 \mathrm{MW}$, in 5 condensing energy groups of $210 \mathrm{MW}$ each and a group of $235 \mathrm{MW}$, powered by steam boilers, uses coal from the Jiu Valley as main fuel. It was built as a control plant in the national thermal energy system, injecting energy in the northern part of the country, an action that saves energy transport from southern producers and represents a serious reason for system security so that the issue of Hunedoara Energy Complex is not considered to be only a "social problem". It has been in conservation since February 2021, and the entire working staff off 700 employees have opted for layoffs since July 2021.

There are intentions for methane gas-based electricity generation projects [7].

Turceni Thermal Power Plant is the largest thermal power plant in Romania and provides, with an installed capacity of 2,310 MW, about $10 \%$ of Romania's annual electricity consumption. It is part of the Turceni Energy Complex and uses lignite production from the Oltenia coal basins (Motru, Jilt, Rosia, Pesteana). As a measure of environmental protection, the largest gypsum board factory in Romania was built on the platform of the thermal power plant, being the first in the country to use waste resulting from desulphurization processes of gas from a thermal power plant.

The Rovinari thermal power plant has an installed capacity of 1,320 MW, consisting of 4 energy blocks in consortium with opencast mining operations in Rovinari, Tismana and Pinoasa. Rehabilitation and modernization of energy groups are currently underway.

The Craiova Energy Complex with an installed capacity of $930 \mathrm{MW}$ which includes two thermal power plants, Isalnita and Craiova II, and is the third largest in the Oltenia area, is not close to coal deposits so it records additional costs of lignite transportation. 
From data provided by Transelectirca.ro, analysing a graph (fig. 3) of energy production and consumption for the first 7 months of 2021 (January 1-July 25) with attention focused on the share of coal, we considered two months in which Romania had a peak of consumption, the month of January in the cold season and July in the warm season (hot month with temperatures of $39^{\circ} \mathrm{C}$ ).

The peak of consumption, recorded in January, was 9,738 MW with an hourly average consumption of 9,604 MW, of which 1,713 MW produced on coal, 1,835 MW-hydrocarbons, 2,793 MW-water, 1,405 MW-nuclear, $35 \mathrm{MW}$-aeolian, $155 \mathrm{MW}$ - photovoltaic and biomass.

The peak consumption in July was $8,611 \mathrm{MW}$ with an hourly average consumption of 8,552 MW, of which 1,423 MW produced on coal, 1,279 MW - hydrocarbons, 2,501 MW water, 1,236 MW - nuclear, $123 \mathrm{MW}$-aeolian, $711 \mathrm{MW}$ - photovoltaic and $73 \mathrm{MW}$ - biomass $[8]$.

To note that the demand for coal in both cases has a share of about $20 \%$, so one-fifth of total energy production.

For the year 2021, from data communicated by the National Institute of Statistics in Romania, in the first five months, the primary energy resources increased by $8.8 \%$, and the electricity ones increased by $8.4 \%$, compared to the same period of year 2020 .

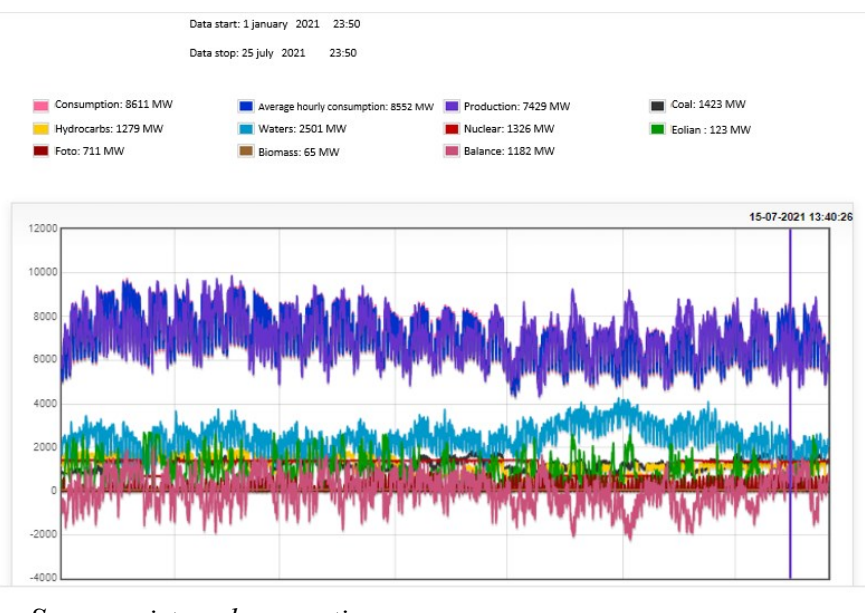

Source: sistemul energetic.ro

Fig.3. Production-consumption diagram of the National Energy System

The main primary energy resources in the period 1.I - 31.V.2021 totalled 14001.7 thousand tons of oil equivalent (tep), increasing by 1128.6 thousand tep compared to the period 1.I 31.V.2020.

The domestic production amounted to 7876.4 thousand tep, increasing by 159.4 thousand tep compared to the same period of the previous year, and the import was 6125.3 thousand tep.

During this period, electricity resources amounted to 28773.1 million $\mathrm{kWh}$, increasing by 2236.1 million $\mathrm{kWh}$, compared to the corresponding period of 2020 :

- Production from thermal power plants was 9120.3 million $\mathrm{kWh}$, increasing by 874.7 million kWh $(+10.6 \%)$;

- Production from hydropower plants was 8389.3 million $\mathrm{kWh}$, increasing by 2745.3 million $\mathrm{kWh}(+48.6 \%)$, and that from nuclear power plants was 4556.9 million $\mathrm{kWh}$, decreasing by 586,1 million $\mathrm{kWh}(-11.4 \%)$; 
- Production from wind power plants in the period 1.I - 31.V.2021 was 2960.7 million $\mathrm{kWh}$, decreasing by 641.5 million $\mathrm{kWh}$ compared to the same period of the previous year;

- Solar energy produced in photovoltaic installations during this period was 668.2 million $\mathrm{kWh}$, down 69.6 million $\mathrm{kWh}$ compared to the corresponding period of 2020 .

The final electricity consumption in this period was 23177.0 million $\mathrm{kWh}, 6.3 \%$ higher than in the corresponding period of 2020; public lighting decreased by $4.7 \%$ and household consumption increased by $8.8 \%$.

Electricity exports were 2905.0 million $\mathrm{kWh}$, up 670.6 million $\mathrm{kWh}$. The own technological consumption in networks and stations was 2691.1 million $\mathrm{kWh}$, increasing by 187.3 million $\mathrm{kWh}$.

So, the image provided by statistics, shows an increase in production (except for wind and photovoltaic installations) and electricity consumption in the first half of 2021 compared to the corresponding period of last year. It can be explained by the fact that the economy has experienced a recovery after the health crisis triggered by the pandemic caused by the new coronavirus COVID - 19 and promulgation of state of emergency at national level.

\section{Recovery programs and future prospects for mining and thermal energy}

The Integrated National Plan for Energy and Climate Change (INPECC) is an obligation of EU member states, according to the new Energy Union Governance Regulation, to develop their energy-climate policy strategies for 10 years, starting with the decade 2021-2030. Following the EU's accession to the Paris Agreement and the publication of the Energy Union Strategy, the Union has taken on an important role in combating climate change through its 5 main dimensions: energy security, decarbonisation, energy efficiency, the internal energy market and research, innovation and competitiveness.

The project provides a comprehensive synthesis of data on the Romanian energy system, including sources of greenhouse gas emissions (GHG) and sets national targets for 2030 in terms of reducing greenhouse gas emissions (GHG), the share of renewable energy sources (RES) in final energy consumption and increasing energy efficiency.

INPECC predicts net increases in electricity generation capacity by 2030 based on almost all forms of primary energy - with the exception of natural gas units, whose aggregate capacity is stagnant, and coal, for which a slight decrease is expected - and forecasts a massive increase in final energy consumption, of $341 \mathrm{TWh}$ in 2030, compared to $269 \mathrm{TWh}$ in the PRIMES 2016 projection (quantitative modelling that was carried out in the process of elaborating the 2016-2030 Energy Strategy), respectively 300 TWh in the Energy Strategy 2019- 2030, in perspective of 2050 [9].

The coal sector will face increasingly severe obstacles and restrictions: rising price of EU ETS certificates, exclusion of new coal-fired units from the capacity market after 2025 (by limiting permissible emissions to $550 \mathrm{~g} \mathrm{CO}_{2} / \mathrm{kWh}$ ), and increasingly severe emission limits. Also, in the absence of new untimely regulations, contrary to EU policies, the high price of the ETS will facilitate the substitution of coal for natural gas in the electricity generating mix [10].

National policies and action plans (including the decarbonisation dimension) to reduce GHG emissions are a key element in limiting the effects of climate change on the environment, economy and society. To support green, low-carbon economic growth, the EU has set ambitious climate and energy targets by 2030. Romania's obligations as a Member State include participation in the EU-ETS scheme for the marketing greenhouse gas emission allowances.

Cross-sectoral policies and measures provide the promoting of investments for development of new low-carbon electricity production capacities by 2030 , in the context in 
which $80 \%$ of existing thermal energy groups have exceeded their normal life, but also of the fact that the energy sector generates over $66 \%$ of GHG emissions.

In this sense, the decarbonization plan proposed by CE Oltenia, which involves the replacement and completion (by 2030) of $1,260 \mathrm{MW}$ in coal-fired power plants with 1,400 MW of natural gas plants and $300 \mathrm{MW}$ of renewable energy (panels photovoltaic), is also under debate.

At CET Craiova 2, the restructuring program includes the closure of the two current groups of $150 \mathrm{MW}$, each starting with 2025. These capacities will be replaced with a 200 MW energy block in gas cogeneration, which will be put into operation a year earlier, in 2024.

In Isalnita, block no. 8 will be closed starting with 2025, and block 7 starting with 2026 . The program shows that each of these groups will be replaced by a gas group of $400 \mathrm{MW}$. Each will be put into operation in the year before the closure of the coal one it replaces, i.e., in 2024 and 2025, respectively.

In Turceni, a $330 \mathrm{MW}$ group will be closed, group 3, in 2025. This is after a gas group of $400 \mathrm{MW}$ will be operational in 2024.

The restructuring program also involves the closure of several coal mines, given that some of the groups will be converted to gas, namely, four of the 12 careers that the company operates. In 2021, the Rovinari quarry will close. In 2024, the Pesteana and Husnicioara quarries will close. In 2027, the Lupoaia quarry will close.

The Recovery and Resilience Mechanism is the main pillar of the temporary financial instrument NextGenerationEU set up by the European Union, in addition to the Multiannual Financial Framework for 2021-2027, to support Member States in meeting challenges posed by the Covid-19 crisis and its economic consequences. The mechanism has allocated a total budget of $€ 672.6$ billion consisting of grants of up to $€ 312.5$ billion and loans of up to $€ 360$ billion.

Access to the Mechanism depends on elaboration of a National Recovery and Resilience Plan that takes into account new climate targets assumed by the respective states through the Integrated National Plans for Energy and Climate Change 2021-2030 and the Country Recommendations made by the European Commission in the margin of the half-yearly report for years 2019 and 2020.

Romania has committed to develop a National Recovery and Resilience Plan, and the allocation of funds from the Recovery and Resilience Mechanism for Romania is approximately 29.2 billion euros. $€ 14.4$ billion of this total would be in the form of grants and $€ 14.935$ billion in loans [11].

The National Recovery and Resilience Plan is built on six pillars: green transition, digital transformation, smart, sustainable and inclusive growth, social and territorial cohesion, health and economic, social and institutional resilience, policies for the next generation, children and young people.

The Green Transition Pillar includes several components, including "Renewable Energy and Energy Efficiency" which aims to implement investments in high efficiency cogeneration and will also include investments for the new energy industry in the Jiu Valley and Gorj. The initial negotiating budget for this component is $€ 1.3$ billion.

Component 6 - Energy, within NRRP proposes 6 reforms and 6 main types of investments. The total proposed budget is 1.62 billion euros.

Reforms:

1. Electricity market reform, by replacing coal in the energy mix and supporting a stimulating legislative and regulatory framework for private investment in generating renewable electricity.

2. Developing a legislative and regulatory framework agreeable to future technologies, in particular hydrogen and storage solutions. 
3. Improving the corporate governance of state-owned companies in the sector.

4. Reducing economy's energy intensity by developing a sustainable mechanism to stimulate energy efficiency in industry.

5. Increasing competitiveness and decarbonising the heating-cooling sector.

6. Decarbonising the transport sector by investing in electricity transmission infrastructure and creating incentives for green transport.

Expected results:

- Increasing the installed capacity of electricity production from renewable sources (wind and solar), from 4408 to $5908 \mathrm{MW}$;

- Contract for construction of the gas network in combination with other low-carbon gaseous fuels;

- $400 \mathrm{~km}$ distribution network of methane gas and other low carbon gas;

- Completion of battery manufacturing capacities with a capacity of at least $0.5 \mathrm{GW}$ per year;

- Completion of the commissioning of at least $100 \mathrm{MW}$ (200 MWh) of electricity storage capacity in order to balance the electricity transmission system and to integrate solar and wind capacities into the network [11].

The Fair Transition Operational Program 2021-2027 is intended to regenerate areas affected by the energy transition given their dependence on fossil fuels or industrial processes with high greenhouse gas emissions and will be applied in Hunedoara, Gorj, Galati, Mures, Prahova and Dolj counties.

The Fair Transition Fund is financial assistance provided at European level for gradual elimination of coal from the energy mix of countries dependent on this fuel. Thus, Priority 2 of the FTOP Framework, from the Fair Transit Fund, investments in the development of technologies for a green energy will be financed, including carbon capture and storage solutions, investments in creating photovoltaic parks connected to the network, one of the solutions being the financing of these parks on the lands belonging to the former mines or factories, thus creating integrated decontamination/regeneration/reconversion projects. Investments of industrial operators in construction of wind farms or photovoltaic farms could also be financed, thus encouraging the transition to a sustainable, low-emission greenhouse gas industry. It will have an allocation of 2.239 billion euros, to which the national cofinancing of 301 million euros will be added, according to the specific Regulation of the Fund for a Fair Transition, published on June $30^{\text {th }}, 2021$ [12].

Other financing schemes set up as non-reimbursable sources of financing are:

- Innovation Fund, which supports innovative technologies that can contribute to GHG reduction, technologies for carbon capture and storage or innovative technologies for production of energy from renewable sources;

- Fund for Modernization, which will support investments in energy efficiency, including investments in high-efficiency cogeneration and energy production from renewable sources;

- Operational Programs will support investments in energy efficiency, including investments in high-efficiency cogeneration for centralized systems (SACET).

Future investments within the FTOP will be based on the Territorial Plans for a Fair Transition (TPFT), elaborated in working groups, along with the County Councils, and supported by the Agencies for Regional Development under coordination of the Ministry of European Investments and Projects.

The European Union's concept of coal mining is presented by Frans Timmermans, Executive Vice President of the European Commission, who leads and implements the European Green Pact and directives that will ensure climate neutrality for 2050, at the opening of this year's ZF Power Summit (23-24 February, 2021): “... Coal has no future. Why does the coal industry have problems all over Europe? For purely economic reasons. Because there is no demand for coal, it is sinking. Billions and billions of subsidies to this 
industry. Billions that could be better used to create a future for the people now working in coal industry ..."[13].

The Hunedoara Energy Complex is currently in a state of insolvency, caused by a series of factors that have as a final result a financial deficit (the value of assets is lower than the value of liabilities). These factors can be briefly explained: expenses for compliance with environmental regulations, negative working capital, high indebtedness, technological equipment with a high degree of wear, sale of electricity and heat at a price lower than the cost of production.

Also, large financial losses are recorded by the Oltenia Energy Complex, caused by the same factors listed above. This energy complex is not yet insolvent.

Debts accumulated over time by these companies amount to hundreds of millions of euros. The obligation to purchase green certificates and periodic increase of prices are retrieved in the costs of extracting a ton of coal, and the cost of certificates reaches over one third of the turnover of the two energy complexes.

\section{Conclusions}

The main responsibility for the climate crisis lies with the fossil fuel industry and in particular extraction, processing and use of coal, which generates over $66 \%$ of GHG emissions, but which is still the primary energy resource in the energy mix, and a strategic fuel to support security of national and regional energy sources. The transition to a new energy system aims at the use of clean technologies with low $\mathrm{CO}_{2}$ emissions and the abandonment of the coal and lignite energy sector.

In the last 5 years (2016-2020) regression of coal sector at the two energy complexes, Hunedoara and Oltenia, which have 6 thermal power plants (Paroseni, Mintia, Turceni, Rovinari, Isalnita and Craiova II) is reflected in the decrease in net production during this period, respectively, $43 \%$ decrease for coal and 33\% decrease for lignite, compared to 2016. The constraints imposed by environmental legislation, the reduction of polluting gases emissions (sulphur dioxide and nitrogen oxides) and greenhouse gases (methane and carbon dioxide) are the main factors that require the restriction of exploitation and reconsideration of the energy strategy at national level.

Analysis of the energy mix recorded on the peak consumption in the winter-summer months (January-July 2021) shows that, at a maximum consumption of 9,738 MW in the cold season, 1,713 MW are produced on coal (18\%), 1,405 MW- nuclear (14.4\%), 2,793 MWwater (28.7\%), 1,835 MW - hydrocarbons (18.8\%), $190 \mathrm{MW}$ - photovoltaic and wind (1.9\%) and at a maximum consumption of $8,611 \mathrm{MW}$ during the warm season, 1,423 MW are produced on coal (17\%), 1,236 MW-nuclear (14.3\%), $2501 \mathrm{MW}$-water (29\%), 1,279 MW hydrocarbons (14.6\%), $834 \mathrm{MW}$ - photovoltaic and wind $(9.7 \%)$. So, the megawatt on coal has almost the same weight in the 2 seasons.

The National Integrated Energy-Climate Change Plan develops energy-climate policy strategies for 10 years, starting with the decade 2021-2030, through 5 main dimensions: energy security, decarbonisation, energy efficiency, the internal energy market and research, innovation and competitiveness. It provides for net increases in electricity generation capacity by 2030 based on almost all forms of primary energy - with the exception of natural gas, whose aggregate capacity is stagnant, and coal.

The decarbonization plan proposed by CE Oltenia, involves the replacement and completion (by 2030) of 1,260 MW in coal-fired power plants with 1,400 MW of natural gas plants and $300 \mathrm{MW}$ of renewable energy (photovoltaic panels). The restructuring program also involves the closure of several coal mines, given that some of the groups will be converted to gas. 
Elaboration of a National Recovery and Resilience Plan that takes into account the new climate targets assumed by the Integrated National Plan for Energy and Climate Change 2021-2030 is very necessary for accessing the Recovery and Resilience Mechanism, as a financial instrument offered by the EU. The Green Transition Pillar of NRRP contains several components, including "Renewable Energy and Energy Efficiency" which aims to implement investments in high efficiency cogeneration and will also include investments for the new energy industry in the Jiu Valley and Gorj.

The Fair Transition Operational Program 2021-2027, designed to regenerate areas affected by the energy transition given their dependence on fossil fuels or industrial processes with high greenhouse gas emissions will be applied in 6 counties including Hunedoara, Gorj. The investments within the FTOP will be based on the Territorial Plans for a Fair Transition.

European Union's view of coal mining is that coal has no future.

\section{References}

1. http://www. ministerulenergiei.ro/Romania's energy strategy 2019-2030, with the perspective of 2050 [Accessed 20.07.2021]

2. N. Anastasiu, E. Constantinescu, T. Murariu, A. Patruti, E.M. Popa, E.R. Stoica Negulescu, Romania's mineral resources Vol. III - Energy resources, (Romanian Academy Publishing House, Bucharest, 2019 - in Romanian)

3. C. Tomescu, E. Chiuzan, D. Cioclea, N. Ianc, C. Boanta, $20^{\text {th }}$ International Multidisciplinary Scientific Geoconference SGEM 2020, Exploration and Mining, Reducing the coal operating capacities in Romania in the context of national energy self-sufficiency and safety insurance, (Albena, Bulgaria, 2020)

4. http://www.academiaromana.ro/bdar/strategiaAR/doc11/Strategia.pdf- (in Romanian), [Accessed 20.07.2021]

5. http://www.insse.ro/ Primary energy resources in the period 1.I-31.V. 2021[Accessed 15.07.2021]

6. C. Tomescu, D. Cioclea, F. Radoi, E. Chiuzan, C. Boanta, $19^{\text {th }}$ International Multidisciplinary Scientific Geoconference SGEM 2019, Exploration and Mining Residual risks encountered in coal mining and closure of mines in the Jiu Valley - Romania, (Albena, Bulgaria 2019)

7. C. Tomescu, D. Cioclea, I. Gherghe, E. Chiuzan, A. Szolosi-Mota, $18^{\text {th }}$ International Multidisciplinary Scientific Geoconference SGEM 2018, Exploration and Mining Section The exploitation of the hard coal of the Jiu Valley coalfield in terms of profitability, on the concepts of energy security and social security, (Albena-Bulgaria, 2018)

8. http://www.sistemul energetic.ro, [Accessed 25.07.2021]

9. https:// ec.europa.eu/energy/sites/ener/files/documents/ro final necp main ro.pdf/ Integrated National Plan in the field of Energy and Climate Change 2021-2030, April 2020, [Accessed 22.07.2021]

10. http://www.euractiv.ro/economic/ The environmental pact: How the Commission sees the transformation of the European economy (in Romanian), [Accessed 15.07.2021]

11. https://mfe.gov.ro/pnrr/ National Recovery and Resilience Plan, Ministry of European Investments and Projects [Accessed 22.07.2021]

12. https://mfe.gov.ro/ Fair Transition Operational Program 2021-2027. [Accessed 25.07.2021].

13. https://www.greenpeace.org/romania/articol/5563/frans-timmermans-coal-has-no-future/, (in Romanian) [Accessed 25.07.2021] 